\title{
HYBRID CINNAMON TEAL X BLUE-WINGED TEAL AT REGINA
}

by Fred W. Lahrman, Saskatchewan Museum of Natural History, Regina

On April 25, 1970, while I was photographing ducks from a blind at the edge of a slough approximately 12 miles northwest of Regina, a bird appeared that I took to be a male hybrid teal. When first seen, it was with a male Blue-winged Teal, but thereafter it was always alone when I observed it. I saw it a second time several days later, but not again until June 6 when I was once more able to photograph it.

The hybrid duck was about the same size as a Blue-winged Teal, but more robust in appearance. It had the blue patch on the wing, which appeared to be almost identical to that of the Bluewinged Teal, the legs were of a similar colour to those of the male Bluewing, and part of the white crescent showed on the head. On the other hand, the general reddish colour of the bird suggested the Cinnamon Teal. The colour pattern of the head did not really fit either species.

I described the bird later in a letter to W. Earl Godfrey, Head of the Vertebrate Zoology Section of the National Museum of Natural Sciences and sent him kodachrome transparencies which I had taken of it. Mr. Godfrey (pers. comm., December 2, 1970), after examining the photographs, expressed his opinion that the bird was a cross between a Blue-winged Teal and a Cinnamon Teal.

Because of the dates of my observations of the hybrid teal, it was of real interest to me to learn that Dr. George Ledingham had seen a duck that he thought might be a Cinnamon X Bluewing hybrid on May 30, 1970, at a slough several miles south of the city of Regina. Again, the general colour of the bird was reddish, but Dr. Ledingham described its head as showing faintly the crescent of a Blue-wing. The more subdued greyish colour of the Blue-wing's head and neck seemed to be combined with the cinnamon colouring. When Dr. Ledingham examined my colour transparency, he felt that this was the bird that he had seen. At the time that Dr. Ledingham observed the hybrid bird, 10 or so drakes were pursuing a single female Blue-wing, and the reddish-coloured one was certainly the dominant male. An early record of a case of hybridism in the wild in these two species is listed by Cockrum (Wilson Bulletin, $64: 142,1952$.)

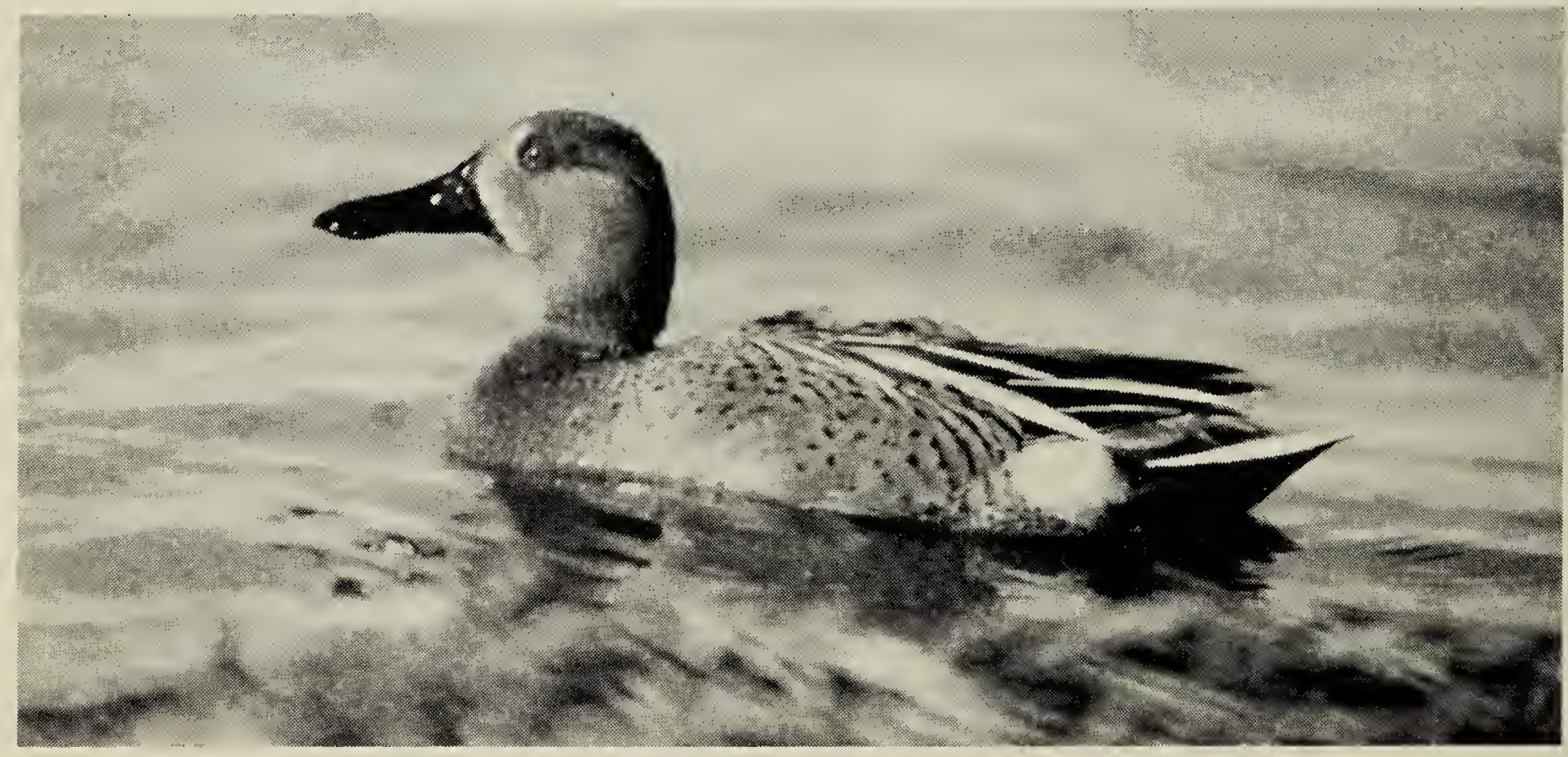

Male hybrid Cinnamon X Blue-winged Teal

Photo by F. W. Lahrman 